\title{
Modified Moving Average (MoMoA) Untuk Peramalan Penjualan Dengan Studi Kasus Sistem Retail
}

\author{
Ellysa Tjandra ${ }^{1}$, Susana Limanto ${ }^{2}$, Liliana $^{3 *}$ \\ 1,2,3Program Studi Teknik Informatika, Universitas Surabaya, Surabaya, Jawa Timur \\ Email: 1ellysa@staff.ubaya.ac.id, ${ }^{2}$ susana@staff.ubaya.ac.id, ${ }^{3 *}$ lili@staff.ubaya.ac.id
}

(Naskah masuk: 3 Des 2020, direvisi: 28 Jan 2021, diterima: 2 Feb 2021)

\begin{abstract}
Abstrak
Salah satu yang menjadi kunci suksesnya manajemen sediaan adalah tersedianya produk yang sesuai dengan jumlah permintaan (demand), namun juga tetap memperhatikan kapasitas penyimpanan produk. Dengan jumlah demand yang dapat diramalkan sebelumnya, maka pihak manajemen dapat mengatur pengadaan barang secara lebih terencana. Salah satu metode peramalan kuantitatif adalah Simple Moving Average, namun metode ini tidak memperhitungkan faktor event yang bisa menyebabkan berbedanya hasil peramalan. Faktor event yang dimaksud adalah hari besar atau hari libur atau musim tertentu yang menyebabkan lonjakan/penurunan jumlah demand secara tidak wajar. Penelitian ini mengusulkan metode Modified Moving Average (MoMoA), sebagai pengembangan dari metode Simple Moving Average dengan menambahkan perhitungan faktor event. Metode kuantitatif yang akan digunakan sebagai pembanding dalam penelitian ini adalah metode Simple Moving Average, Single Exponential Smoothing, dan Least Square Trend. Evaluasi dilakukan dengan melakukan peramalan menggunakan empat macam metode pada periode terjadinya event hari Raya Idul Fitri dan membandingkan hasilnya dengan data penjualan riil. Hasil evaluasi menunjukkan bahwa metode MoMoA memberikan hasil 58\% lebih baik dibandingkan metode lainnya, yaitu hasil peramalan dengan metode ini lebih mendekati riil dibandingkan dengan ketiga metode lainnya. Pada akhirnya, diharapkan penggunaan metode ini dapat membantu perusahaan dalam mengatur sediaan produk secara lebih terencana.
\end{abstract}

Kata Kunci: peramalan, stok, moving average, retail, Modified Moving Average.

\section{Modified Moving Average (MoMoA) for Sales Forecasting with Retail System Case Study}

\begin{abstract}
One of the keys to successful supply management is the availability of products that is both in accordance with the number of requests (demand) and yet attentive to the product storage capacity. The management could organize the procurement of goods in a better planned arrangement, if the amount of demand could be anticipated in advance. One of the methods of quantitative forecasting is using Simple Moving Average. However, this method does not take into account the event factors that can lead to different forecasting results. Event factors here refer to holidays, national days, or certain festive seasons that can generate unnatural increase/decrease in the number of demands. This study proposes the Modified Moving Average (MoMoA) method as an advancement of the Simple Moving Average method by adding the calculation of event factor. As comparison in this research, the quantitative method that will be included are the Simple Moving Average, Single Exponential Smoothing, and Least Square Trend. The assessment is performed using four different forecasting methods during the Eid al-Fitr event and then compared using real sales data. The results of the evaluation show that the MoMoA gives $58 \%$ better results compared to other methods, that is, these forecasting results are closer to actual numbers than the other three methods. Subsequently, it is hoped that this method can facilitate companies in organizing product arrangement in a more planned manner.
\end{abstract}

Keywords: forecasting, stock, moving average, retail, Modified Moving Average. 


\section{PENDAHULUAN}

Manajemen sediaan adalah salah satu yang penting dalam sistem retail. Dengan manajemen sediaan yang baik maka akan menjadi keunggulan kompetitif bagi perusahaan. Salah satu yang menjadi kunci suksesnya manajemen sediaan adalah tersedianya produk yang sesuai dengan jumlah permintaan (demand), namun juga tetap memperhatikan kapasitas penyimpanan produk (storage). Jika jumlah sediaan di bawah jumlah demand dari produk tersebut, maka akan menyebabkan tidak terpenuhinya demand, dan hal ini dapat mengakibatkan menurunnya kepuasan pelanggan atau bahkan kehilangan pelanggan. Namun jika jumlah sediaan di atas jumlah demand, akan membutuhkan storage yang lebih besar untuk menyimpan kelebihan sediaan, sehingga membutuhkan biaya penyimpanan (storage cost) yang lebih besar, selain itu jika produk tersebut memiliki umur produk atau masa kadaluarsa maka resiko kerusakan produk lebih besar. Untuk menentukan jumlah sediaan yang sesuai maka harus diketahui jumlah demand dari suatu produk secara tepat, terutama jumlah demand untuk periode yang akan datang, sehingga pihak manajemen dapat mengatur dan mengantisipasinya. Untuk mengetahui jumlah demand pada periode mendatang, diperlukan proses peramalan yang dapat menghasilkan prediksi jumlah demand pada periode tertentu. Dengan jumlah demand yang dapat diramalkan sebelumnya, maka pihak manajemen dapat mengatur pengadaan barang secara lebih terencana.

Metode Simple Moving Average telah digunakan secara luas untuk melakukan peramalan. Metode ini digunakan untuk mencari rata-rata bergerak dari beberapa periode waktu secara berturut-turut. Untuk menghasilkan urutan dalam moving average, dilakukan perhitungan rata-rata terhadap beberapa observasi [1]. Metode ini sangat cocok untuk digunakan jika data yang ada tidak terlalu bervariasi dari waktu ke waktu. Beberapa penelitian yang memanfaatkan metode Simple Moving Average adalah peramalan nilai saham [1], peramalan jumlah penjualan obat [2], peramalan penjualan bahan bakar minyak jenis premium [3], dan enkripsi Sinyal [4].

Dengan metode Simple Moving Average maka prediksi jumlah demand suatu produk dapat diperoleh, di mana data acuan dari metode ini diperoleh dari data history transaksi yang telah berlangsung dalam perusahaan. Namun metode Simple Moving Average yang umum digunakan tidak memperhitungkan faktor event yang bisa menyebabkan berbedanya hasil peramalan atau ketidaktepatan hasil peramalan dengan kondisi riil. Faktor event yang dimaksud adalah hari besar atau hari libur atau musim tertentu yang menyebabkan lonjakan/penurunan jumlah demand secara tidak wajar. Contoh event adalah lebaran, imlek, natal/tahun baru, awal tahun ajaran sekolah, dan beberapa event lainnya.

Penelitian ini bertujuan untuk melengkapi atau memodifikasi metode Simple Moving Average yang sudah ada sehingga dapat memperhitungkan faktor event, kemudian membuat sebuah perangkat lunak yang dapat digunakan perusahaan untuk memprediksi jumlah demand di masa mendatang, sehingga diharapkan peramalan yang dilakukan memiliki hasil prediksi yang lebih mendekati riil. Penelitian ini mengambil studi kasus pada perusahaan retail yang menjual barang kebutuhan sehari-hari. Luaran dari penelitian ini adalah berupa perangkat lunak peramalan demand pada sistem retail serta laporan dokumentasi penelitian. Selain itu, penelitian ini juga akan dipublikasikan secara ilmiah sesuai tahapan penelitian. Dengan terlaksananya penelitian ini diharapkan hasil peramalan jumlah demand dapat lebih mendekati riil, sehingga perusahaan dapat mengatur sediaan produk secara lebih terencana.

\section{DASAR TEORI}

Peramalan merupakan sebuah proses untuk melakukan prediksi mengenai apa yang akan terjadi di masa mendatang berdasarkan data yang ada atau pengalaman di masa lalu. Contoh, badan meteorologi meramalkan keadaan cuaca suatu daerah dan pengusaha meramalkan besarnya permintaan atas produk yang diproduksi oleh perusahaan. Hasil dari peramalan biasanya dimanfaatkan untuk mengambil keputusan.

Saat ini sudah banyak metode peramalan yang tersedia. Masing-masing metode mempunyai karakteristik tersendiri sehingga pemilihan metode perlu mempertimbangkan karakteristik dari metode tersebut agar hasil peramalan yang diberikan tidak menyimpang jauh dari kondisi riil. Beberapa karakteristik yang perlu dipertimbangkan saat memilih metode peramalan adalah kerangka waktu, keberadaan pola, dan jumlah variabel [5].

Berdasarkan kerangka waktu, peramalan dapat dibedakan menjadi tiga macam, yaitu peramalan jangka pendek, peramalan jangka menengah, dan peramalan jangka panjang. Peramalan jangka pendek merupakan proses meramalkan untuk masa depan yang segera datang. Peramalan jangka pendek biasanya digunakan untuk meramalkan kebutuhan sumber daya harian atau permintaan harian [5]. Peramalan jangka menengah merupakan proses meramalkan apa yang akan terjadi 1 sampai 12 bulan ke depan. Peramalan jangka menengah biasanya digunakan untuk menentukan rencana produksi tahunan. Sedangkan peramalan jangka panjang merupakan proses meramalkan untuk lebih dari 1 tahun ke depan. Peramalan jangka panjang biasanya digunakan untuk merencanakan produk baru, membangun fasilitas baru, atau menjamin adanya pembiayaan jangka panjang.

Ada kalanya kondisi yang ada menunjukkan adanya pola tertentu seperti tren naik/turun, musiman, ataupun siklus/berulang. Pola musiman adalah pergerakan yang terjadi karena adanya kejadian tertentu. Sedangkan siklus adalah pergerakan naik dan turun yang berulang sepanjang suatu periode waktu yang panjang. Namun tidak jarang kondisi yang ada juga terjadi secara acak.

\section{A. Simple Moving Average}

Metode ini tergolong metode yang mempunyai karakteristik kerangka waktu khususnya jangka pendek. Peramalan dilakukan dengan mengasumsikan bahwa apa yang telah terjadi di masa lalu akan terus terjadi di masa mendatang. Untuk itu, data yang digunakan untuk melakukan peramalan 
hanyalah data saat ini tanpa memperhitungkan pola yang mungkin ada.

Metode Simple Moving Average merupakan sebuah metode yang biasa digunakan untuk melakukan peramalan berdasarkan rata-rata bergerak dari data n periode terakhir [2], [3], [4], [6]. Metode ini digunakan untuk meramalkan nilai untuk satu periode ke depan. Rumus yang digunakan untuk melakukan peramalan dengan metode Simple Moving Average dapat dilihat pada Persamaan 1. Metode ini sangat cocok untuk digunakan jika data yang ada tidak terlalu bervariasi dari waktu ke waktu. Penentuan jumlah periode yang tepat digunakan dalam peramalan menggunakan metode Simple Moving Average dilakukan secara trial and error.

$F_{t}=\frac{F_{t-1}+F_{t-2}+\ldots+F_{t-n}}{n}$

\section{Keterangan:}

$\mathrm{F}_{\mathrm{t}} \quad=$ hasil peramalan untuk periode $\mathrm{t}$

$\mathrm{F}_{\mathrm{t}-1}=$ data dari periode $\mathrm{t}-1$

$\mathrm{F}_{\mathrm{t}-2}=$ data dari periode $\mathrm{t}-2$

$\mathrm{F}_{\mathrm{t}-\mathrm{n}}=$ data dari periode $\mathrm{t}-\mathrm{n}$

$\mathrm{n} \quad$ = jumlah periode yang digunakan dalam peramalan

Beberapa penelitian yang memanfaatkan metode Simple Moving Average adalah peramalan nilai saham [1], peramalan jumlah penjualan obat [2], peramalan penjualan bahan bakar minyak jenis premium [3], dan enkripsi sinyal [4]. Namun metode ini mempunyai beberapa kelemahan karena metode ini memberikan bobot yang sama untuk setiap data sehingga hasil yang diberikan terkadang berbeda cukup jauh dari data terakhir. Selain itu, metode ini tidak mengantisipasi adanya trend atau musiman [6]. Oleh karena itu telah dilakukan beberapa penelitian untuk mengembangkan metode Simple Moving Average. Penelitian yang dilakukan oleh Shou Hsing Shih dan Tsokos (2008) memodifikasi metode Simple Moving Average menjadi Weighted Moving Average dengan cara mengkombinasikan metode kth-Simple Moving Average dengan ARIMA (p, d, q) [6]. Penelitian yang dilakukan oleh Nguyen meramalkan pergerakan harga saham dan signal menjual atau membeli dengan menggunakan metode Variable Simple Moving Average yang dimodifikasi dengan memberikan bobot lebih besar pada data terakhir [7]. Walaupun metode ini mempunyai kelemahan, metode ini merupakan metode yang mudah dan cepat untuk diaplikasikan.

\section{B. Single Exponential Smoothing}

Metode ini merupakan variasi dari metode Weighted Moving Average, yaitu memberikan bobot yang lebih kuat pada data yang terakhir daripada data awal. Perbedaan pembobotan ini berguna jika perubahan terakhir merupakan akibat dari perubahan aktual daripada fluktuasi acak. Metode Single Exponential Smoothing banyak digunakan untuk meramal data masa depan, dengan data yang sedikit atau yang fluktuatif [8], atau data yang tidak dipengaruhi oleh tren [9]. Metode ini diperkenalkan oleh Holt, 1957 [10]. Holt (1957) mengembangkan metode ini menjadi linear exponential smoothing yang memungkinkan peramalan data dengan tren. Dalam penelitiannya, Holt (1957) memberikan saran pengembangan metode ini untuk data musiman. Pengembangannya dilakukan oleh Winters (1960) yang kemudian dikenal sebagai metode Holt-Winters [11].

Rumus yang digunakan untuk melakukan peramalan dengan metode Single Exponential Smoothing dapat dilihat pada Persamaan 2 [12], [13]. Alpha pada Persamaan 2 menyatakan pembobotan untuk data terbaru dan $(1-\alpha)$ menyatakan pembobotan untuk data periode sebelumnya. Jadi semakin tinggi nilai $\alpha$ maka hasil peramalan semakin sensitif terhadap data terakhir. Sebaliknya semakin kecil nilai $\alpha$ maka semakin besar efek pemulusannya. Nilai $\alpha$ yang sering digunakan adalah 0.01 sampai 0.5 [5]. Namun nilai $\alpha$ yang terbaik biasanya didapat dari trial and error.

$\widehat{Y}_{t+1}=\alpha Y_{t}+(1-\alpha) \hat{Y}_{t}$

Keterangan:

$\hat{Y}_{t+1}=$ nilai ramalan untuk periode $\mathrm{t}+1$

$\alpha \quad=$ konstanta pemulusan. $0 \leq \alpha \leq 1$

$Y_{t} \quad$ = data baru atau nilai $\mathrm{Y}$ yang sebenarnya pada periode $\mathrm{t}$

$\hat{Y}_{t} \quad=$ nilai ramalan sebelumnya untuk periode $t$ atau rata-rata pemulusan hingga periode $\mathrm{t}-1$

Pada saat pertama kali melakukan peramalan, nilai belum tersedia. Agar proses peramalan dapat tetap berjalan maka nilai diambil dari nilai $\mathrm{Y}_{\mathrm{t}}$, rata-rata dari 3 sampai 4 data periode sebelumnya, rata-rata hasil peramalan sebelumnya, atau ditentukan secara subjektif.

Beberapa penelitian menggunakan metode Single Exponential Smoothing untuk meramalkan harga daging [14], tingkat penjualan pakaian di PT Media Cemara [8], tingkat permintaan warga AS untuk perjalanan ke Durban, Afrika Selatan [15], tingkat penjualan bahan bakar [3] serta tingkat kebutuhan penggunaan listrik [16].

\section{Least Square Trend}

Metode Least Square Trend merupakan salah satu metode yang biasa digunakan untuk mengidentifikasi adanya tren [17]. Metode ini digunakan untuk mencari relasi linier terbaik antar 2 (dua) buah variabel, dependent variable dan independent variable [17], [18]. Dalam metode peramalan, waktu merupakan variabel independen dan nilai time series merupakan variabel dependent.

Metode Least Square Trend dapat digunakan untuk meramalkan nilai dari dependent variable berdasarkan nilai dari independent variable [18]. Rumus yang digunakan untuk melakukan peramalan dengan metode Least Square Trend dapat dilihat pada Persamaan 3 [5]. Nilai dari parameter b dapat dihitung dengan menggunakan rumus pada Persamaan 4 dan nilai parameter a dapat dihitung dengan menggunakan rumus pada Persamaan 5 [17], [18]. Hasil prediksi diusahakan dapat meminimalkan error.

$$
\hat{Y}=a+b t
$$


$b=\frac{n \sum t Y-\sum Y \sum t}{n \sum t^{2}-\left(\sum t\right)^{2}}$

$a=\frac{\sum Y}{n}-b \frac{\sum t}{n}$

Keterangan:

$\hat{\mathrm{Y}}=$ nilai ramalan untuk periode $\mathrm{t}$ tertentu

$\mathrm{a}=$ nilai intercept $($ estimasi nilai $\mathrm{Y}$ pada $\mathrm{t}=0$ )

$\mathrm{b}=$ nilai slope/tren (rata-rata perubahan dalam Y untuk tiap perubahan $\mathrm{t}$

$\mathrm{t}=$ satuan nilai waktu yang dipilih

Metode ini cocok digunakan untuk peramalan jangka waktu menengah atau jangka waktu panjang untuk menghindari yang tidak berubah [5]. Beberapa contoh penerapan metode Least Square Trend adalah untuk mengidentifikasi tren dalam sebuah jaringan satelit [19], tren pasar saham [20], prediksi output dengan tenaga matahari [21], dan masih banyak lagi penerapan metode ini.

\section{Mean Square Error}

Metode peramalan yang bagus adalah metode yang dapat memberikan tingkat akurasi yang tinggi dalam arti memberikan eror yang rendah. Ada banyak cara untuk mengetahui tingkat akurasi hasil peramalan, salah satu diantaranya adalah Mean Square Error (MSE). MSE dapat dihitung dengan menggunakan Persamaan 6.

$M S E=\frac{\sum_{t=1}^{n}\left(A_{t}-F_{t}\right)^{2}}{n}$

Keterangan:

MSE = Mean Square Error

$\mathrm{F}_{\mathrm{t}} \quad=$ Hasil peramalan untuk periode $\mathrm{t}$

$\mathrm{A}_{\mathrm{t}} \quad=$ Data aktual untuk periode $\mathrm{t}$

$\mathrm{n} \quad=$ Jumlah periode

\section{METODE PENELITIAN}

Penelitian ini dilakukan dengan beberapa tahapan. Gambaran dari tahapan proses penelitian dapat dilihat pada Gambar 1. Adapun tahapan proses metode MoMoA meliputi:

1. Melakukan pengecekan apakah tanggal yang akan diramalkan ada di daftar event yang ada. Jika tanggal tersebut tidak ada pada daftar event, maka lakukan peramalan menggunakan metode Simple Moving Average. Jika tanggal tersebut ada di dalam daftar event, lakukan pengecekan, tanggal tersebut merupakan hari keberapa dari event tersebut. Contoh: Event Lebaran tahun 2013 jatuh pada tanggal 8 - 9 Agustus 2013. Tanggal mulai pengaruh event sampai tanggal selesai pengaruh event dapat dihitung menggunakan Persamaan 7.

$$
\left.\begin{array}{l}
t_{\mathrm{se}}=t_{s}-h_{s} \\
t_{\mathrm{ee}}=t_{e}-h_{e}
\end{array}\right\}
$$

Keterangan:

$\mathrm{t}_{\mathrm{se}}=$ tanggal mulai pengaruh suatu event $t_{e e}=$ tanggal selesai pengaruh suatu event

$\mathrm{t}_{\mathrm{s}}=$ tanggal awal event

$\mathrm{t}_{\mathrm{e}}=$ tanggal berakhirnya event

$\mathrm{h}_{\mathrm{s}}=$ jumlah hari pengaruh sebelum tanggal event

$\mathrm{h}_{\mathrm{e}}=$ jumlah hari pengaruh setelah tanggal event

Misalkan untuk event Idul Fitri diketahui berpengaruh $\mathrm{H}-14$ sampai $\mathrm{H}+0$, maka 14 menjadi $\mathrm{h}_{\mathrm{s}}$, dan 0 menjadi $\mathrm{h}_{\mathrm{e}}$. Jadi jika ts untuk Idul Fitri jatuh pada 8 Agustus 2013 dan $\mathrm{t}_{\mathrm{e}}$ jatuh pada 9 Agustus 2013, maka $\mathrm{t}_{\text {se }}$ jatuh pada $25 \mathrm{Juli}$ 2013 (diperoleh dari tanggal 8 Agustus 2013 dikurangi dengan 14 hari), dan $t_{\text {ee }}$ jatuh pada tanggal 9 Agustus 2013 (diperoleh dari tanggal 9 Agustus 2013 ditambah dengan 0 hari). Hal ini berarti event lebaran tersebut akan berpengaruh terhadap penjualan mulai tanggal 25 Juli sampai dengan 9 Agustus 2013. Apabila suatu barang akan diramalkan pada tanggal 9 Agustus 2013, maka harus dicari tanggal tersebut merupakan urutan hari keberapa terhitung sejak tanggal mulai pengaruh event. Urutan hari keberapa dapat dihitung melalui Persamaan 8.

$O_{d}=t_{f}-t_{s e}+1$

Keterangan:

$\mathrm{O}_{\mathrm{d}}=$ urutan hari keberapa di range event terhitung sejak $\mathrm{t}_{\mathrm{se}}$

$\mathrm{t}_{\mathrm{f}}=$ tanggal peramalan

$\mathrm{t}_{\mathrm{se}}=$ tanggal mulai pengaruh suatu event

Perhitungan dengan menggunakan Persamaan 8 menghasilkan bahwa tanggal 9 Agustus 2013 merupakan urutan hari ke-16 $\left(\mathrm{O}_{\mathrm{d}}=16\right)$ dalam event tersebut (didapat dari 9 Agustus 2013 dikurangi dengan 25 Juli 2013) + 1) sejak $\mathrm{t}_{\mathrm{se}} 25$ Juli 2013. Jadi tanggal pengambilan data yang akan digunakan untuk peramalan dapat dihitung dengan menggunakan Persamaan 9.

$t_{h}=\mathrm{t}_{\mathrm{se}}+O_{d}-1$

Keterangan:

$\mathrm{t}_{\mathrm{h}}=$ tanggal data history

$\mathrm{t}_{\mathrm{se}}=$ tanggal mulai pengaruh suatu event

$\mathrm{O}_{\mathrm{d}}=$ urutan hari keberapa di range event terhitung sejak $\mathrm{t}_{\mathrm{se}}$

2. Mengambil data penjualan barang tersebut pada urutan hari yang sama selama k data event periode sebelumnya. Apabila event yang digunakan adalah event tahunan, maka artinya $\mathrm{k}$ tahun sebelumnya. Misal $\mathrm{k}=3$, dan data yang akan diramalkan adalah data yang masuk dalam event tahun ke-N, maka akan diambil 3 data penjualan pada urutan hari yang sama di tahun N-1, N-2, N-3. Sebagai contoh, akan diramalkan event Lebaran untuk tahun 2013, maka dibutuhkan data penjualan yang terjadi di urutan hari yang sama pada 3 (tiga) event Lebaran sebelumnya, yaitu Lebaran tahun 2012, 2011, 2010. Karena tanggal untuk event lebaran di tahun 2012, 2011, dan 2010 bisa berbeda setiap tahunnya, maka metode ini akan mengambil data penjualan barang dengan ketentuan seperti pada Tabel 1. 
Jadi data penjualan barang yang akan diambil adalah penjualan tanggal 20 Agustus 2012, 31 Agustus 2011, dan 11 September 2010.

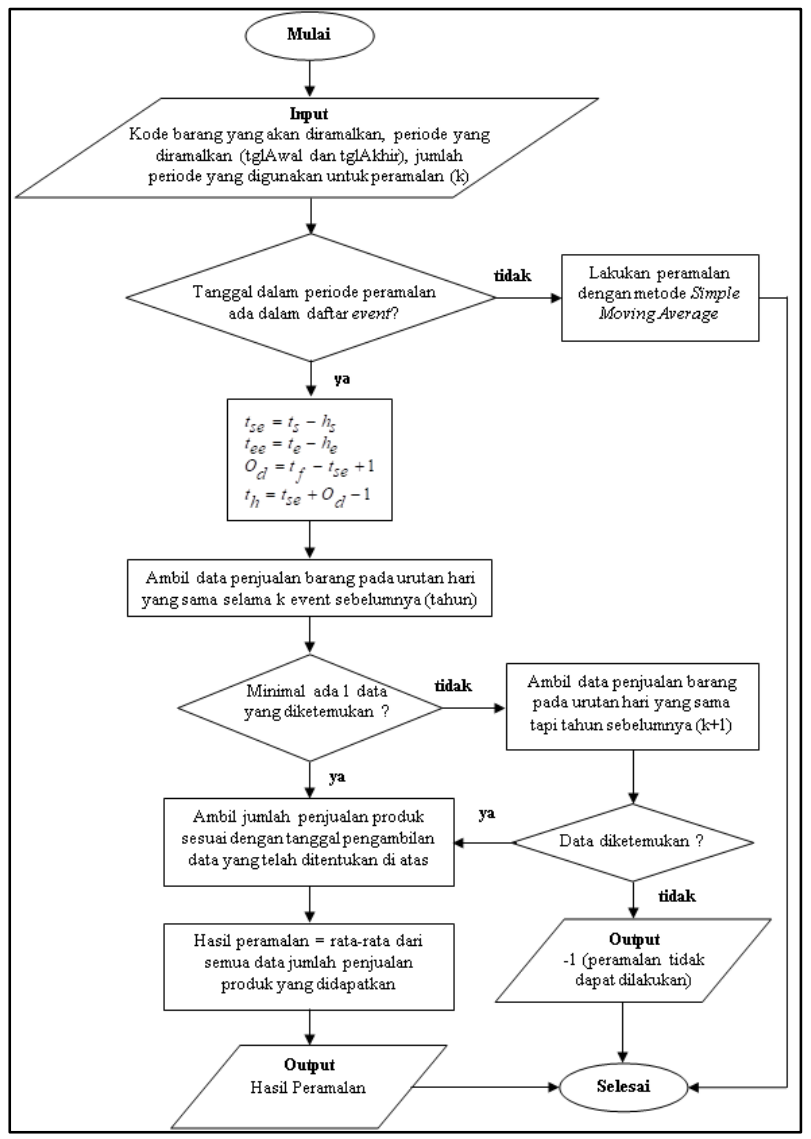

Gambar 1. Tahapan Metode MoMoA

3. Mencari jumlah penjualan produk sesuai tanggal pengambilan data history $\left(\mathrm{t}_{\mathrm{h}}\right)$ yang telah ditentukan pada langkah 2, Jika tidak ditemukan data penjualan produk pada tanggal pengambilan data history di tahun tersebut maka data akan diambil dari data pada event tahun sebelumnya (mundur). Proses peramalan membutuhkan minimal 1 (satu) data penjualan dari semua tanggal pengambilan data history yang ditentukan tersebut. Jika sama sekali tidak ditemukan data penjualan pada tanggal pengambilan data yang ditentukan maka proses peramalan tidak dapat dilakukan (hasil peramalan $=-1$ ).

4. Menghitung rata-rata dari semua data tersebut sebagai data permintaan barang hasil peramalan. Jika hasil rata-rata tidak bulat maka dilakukan pembulatan ke atas untuk menjamin stok barang selalu tersedia (tidak kurang). Contoh hasil peramalan dapat dilihat pada Tabel 2.

\section{HASIL DAN PEMBAHASAN}

Analisis dilakukan terhadap metode Simple Moving Average dan Single Exponential Smoothing untuk menentukan nilai parameter terbaik yang akan digunakan sebagai default nilai pada aplikasi yang dikembangkan. Pada metode Simple Moving Average akan ditentukan nilai dari parameter k yang paling optimal, sedangkan pada metode Single Exponential Smoothing akan ditentukan nilai dari parameter $\alpha$ yang optimal.

\section{A. Hasil Metode Simple Moving Average}

Pada program peramalan dengan metode Simple Moving Average yang dikembangkan dalam penelitian ini, nilai $\mathrm{k}$ dirancang dapat diinputkan oleh pengguna. Namun, perlu disediakan standar nilai k yang optimal sesuai dengan data yang ada agar nilai k yang nantinya diinputkan oleh pengguna tidak memberikan hasil peramalan yang jauh dari kondisi riil. Walaupun demikian, perubahan nilai $\mathrm{k}$ yang optimal tetap dimungkinkan melalui inputan. Untuk menentukan nilai $\mathrm{k}$ yang optimal berdasarkan kondisi riil, dilakukan analisis terhadap data penjualan yang ada. Data 2016 dipilih untuk digunakan dalam penelitian ini dikarenakan data penjualan tahun 2016 dapat digunakan untuk melakukan peramalan dengan metode Simple Moving Average k = 30 dengan hari libur diganti dengan hasil peramalan.

Tabel 1. Tanggal Pengambilan Data History untuk Event Tertentu

\begin{tabular}{lllllllll}
\hline Tahun & \multicolumn{1}{c}{$\mathbf{t}_{\mathbf{s}}$} & \multicolumn{1}{c}{$\mathbf{t}_{\mathbf{e}}$} & $\mathbf{h}_{\mathbf{s}}$ & $\mathbf{h}_{\mathbf{e}}$ & $\mathbf{t}_{\mathbf{s e}}$ & $\mathbf{t}_{\mathbf{e e}}$ & $\mathbf{O}_{\mathbf{d}}$ & $\mathbf{t}_{\mathbf{h}}$ \\
\hline 2013 & 8 Agustus & 9 Agustus & 14 & 0 & 25 Juli & 9 Agustus & - & - \\
\hline 2012 & 19 Agustus & 20 Agustus & 14 & 0 & 5 Agustus & 20 Agustus & 16 & 20 Agustus \\
\hline 2011 & 30 Agustus & 31 Agustus & 14 & 0 & 16 Agustus & 31 Agustus & 16 & 31 Agustus \\
\hline 2010 & 10 September & 11 September & 14 & 0 & 27 Agustus & 11 September & 16 & 11 September \\
\hline
\end{tabular}

Tabel 2. Data Penjualan pada Tanggal Pengambilan Data History $\left(t_{h}\right)$

\begin{tabular}{llr}
\hline Tahun & \multicolumn{1}{c}{$\mathbf{t}_{\mathbf{h}}$} & $\begin{array}{l}\text { Data Jumlah } \\
\text { Penjualan }\end{array}$ \\
\hline 2012 & 20 Agustus & 120 \\
\hline 2011 & 31 Agustus & 100 \\
\hline 2010 & 11 September & 80 \\
\hline Hasil peramalan & $\mathbf{9 8}$ \\
\hline
\end{tabular}


Analisis dilakukan dengan menjalankan peramalan permintaan barang dari bulan Juni sampai bulan Desember 2016 dengan mengambil $\mathrm{k}=3, \mathrm{k}=5, \mathrm{k}=7, \mathrm{k}=15, \mathrm{k}=30$. Peramalan dimulai bulan Juni 2016 dikarenakan untuk menganalisa data dengan $\mathrm{k}=30$ dan hari libur diganti dengan hasil peramalan, dibutuhkan data penjualan yang didalamnya terdapat 30 data penjualan secara berurutan (tanpa ada hari libur). Hal ini sulit dilakukan mengingat toko yang menjadi objek penelitian seringkali libur di hari minggu kecuali karena alasan tertentu, toko tetap buka. Nilai k yang dipakai dalam analisis dibatasi paling besar hanya 30 hari karena sesuai dengan teori yang ada, metode Simple Moving Average cocok digunakan untuk peramalan jangka pendek. Peramalan dengan metode Simple Moving Average dilakukan dengan menghitung rata-rata bergerak selama $\mathrm{k}$ periode. Namun, karena pada hari-hari tertentu toko libur, maka ada data yang dibutuhkan untuk peramalan menjadi tidak ada.

Ada beberapa macam cara untuk mengganti data yang tidak ada, diantaranya adalah mengganti data yang tidak ada dengan data sebelumnya dan mengganti data yang tidak ada dengan data hasil peramalan. Untuk menentukan cara mana yang lebih baik, pada penelitian ini akan dilakukan peramalan dengan kedua macam cara tersebut. Penentuan cara yang lebih baik dilakukan berdasarkan nilai Mean Square Error (MSE) dari 10 macam barang terlaris di tahun 2016.
Perhitungan MSE dilakukan dengan membandingkan hasil peramalan dengan data sebenarnya. Hasil perhitungan MSE jika data yang tidak ada diganti dengan data sebelumnya dapat dilihat pada Tabel 3. Sedangkan hasil perhitungan MSE jika data yang tidak ada diganti dengan data hasil peramalan dapat dilihat pada Tabel 4 . Tabel 3 dan Tabel 4 menunjukkan bahwa persentase perbedaan MSE pada Tabel 4 terhadap MSE pada Tabel 3 paling besar adalah $2.34 \%$. Selain itu, juga terlihat adanya kecenderungan bahwa semakin besar nilai $\mathrm{k}$, maka rata-rata MSE semakin kecil. Nilai k yang memberikan rata-rata MSE paling kecil adalah 30 hari. Selain itu, kedua tabel menunjukkan bahwa rata-rata MSE dari penggunaan data peramalan untuk mengganti data yang tidak ada untuk nilai $\mathrm{k}$ minimal 7 lebih baik dari pada menggunakan data sebelumnya. Namun peramalan dengan menggunakan $\mathrm{k}=30$ dan mengganti data yang tidak ada dengan data peramalan sangat sulit dilakukan, mengingat pada hari minggu toko libur kecuali menjelang event-event tertentu. Peramalan dengan mengganti data yang tidak ada dengan data peramalan membutuhkan $\mathrm{k}$ data berurutan, yang mana hal ini sulit dilakukan kecuali nilai k di bawah 7 . Untuk itu pada program yang akan dikembangkan dalam penelitian ini, data yang tidak ada akan diganti dengan data sebelumnya dengan default nilai $\mathrm{k}=30$.

Tabel 3. MSE pada Peramalan dengan Penggantian Data dari Data Sebelumnya

\begin{tabular}{rlrrrrrr}
\hline & & \multicolumn{7}{c}{ Mean Square Error (MSE) } \\
\cline { 3 - 8 } No. & \multicolumn{1}{c}{ Nama Barang } & $\mathbf{K = 3}$ & $\mathbf{K}=\mathbf{5}$ & $\mathbf{K}=\mathbf{7}$ & $\mathbf{K}=\mathbf{1 0}$ & $\mathbf{K}=\mathbf{1 5}$ & \multicolumn{1}{c}{$\mathbf{K}=\mathbf{3 0}$} \\
\hline 1. & ANDO N. HAWAII MEN & $9.026,97$ & $7.669,32$ & $7.844,57$ & $7.517,43$ & $7.096,88$ & $6.878,44$ \\
\hline 2. & SR RANTING HAK B & $4.654,26$ & $4.846,75$ & $3.792,72$ & $3.662,88$ & $3.671,44$ & $3.639,60$ \\
\hline 3. & TALI PLINTIR HT & 0,00 & 0,14 & 0,00 & 0,00 & 0,00 & 46,73 \\
\hline 4. & KUBOTA LAPIS 10-10.5 & $22.700,64$ & $18.700,79$ & $19.511,76$ & $19.038,76$ & $18.454,80$ & $18.286,08$ \\
\hline 5. & KUBOTA LAPIS T & $42.469,76$ & $36.320,10$ & $38.495,72$ & $38.468,16$ & $38.086,74$ & $37.333,61$ \\
\hline 6. & SWL OKINA 502 HJJ B & $55.372,04$ & $41.572,74$ & $47.202,54$ & $45.492,52$ & $43.979,56$ & $41.448,41$ \\
\hline 7. & HH 112E L 20/25 & $3.922,17$ & $4.575,84$ & $3.310,64$ & $3.161,64$ & $3.004,62$ & $2.941,21$ \\
\hline 8. & KUBOTA LAPIS B & $29.892,64$ & $27.367,21$ & $26.928,53$ & $27.264,65$ & $27.285,04$ & $27.175,21$ \\
\hline 9. & SWL 05 D 10-10.5 & $211.535,46$ & $189.859,26$ & $197.367,43$ & $192.318,34$ & $189.625,02$ & $179.103,99$ \\
\hline 10. & SWL 05 SR & $240.754,80$ & $223.767,90$ & $222.263,52$ & $215.691,06$ & $210.964,62$ & $201.701,99$ \\
\hline Rata-Rata MSE & $62.032,87$ & $55.468,01$ & $56.671,74$ & $55.261,54$ & $54.216,87$ & $51.855,53$ \\
\hline
\end{tabular}

Tabel 4. MSE pada Peramalan dengan Penggantian Data dari Data Peramalan

\begin{tabular}{rlrrrrrr}
\hline & & \multicolumn{5}{c}{ Mean Square Error (MSE) } \\
\cline { 3 - 8 } No. & \multicolumn{1}{c}{ Nama Barang } & $\mathbf{K = 3}$ & $\mathbf{K}=\mathbf{5}$ & $\mathbf{K}=\mathbf{7}$ & $\mathbf{K}=\mathbf{1 0}$ & \multicolumn{1}{c}{$\mathbf{1 5}$} & \multicolumn{1}{c}{$\mathbf{K}=\mathbf{3 0}$} \\
\hline 1. & ANDO N. HAWAII MEN & $9.238,37$ & $7.956,79$ & $7.771,55$ & $7.606,4$ & $7.304,07$ & $6.833,44$ \\
\hline 2. & SR RANTING HAK B & $4.596,54$ & $4.025,00$ & $3.763,14$ & $3.732,20$ & $3.658,38$ & $3.695,40$ \\
\hline 3. & TALI PLINTIR HT & 0,00 & 0,00 & 0,00 & 0,00 & 0,00 & 35,05 \\
\hline 4. & KUBOTA LAPIS 10-10.5 & $22.608,90$ & $20.091,98$ & $19.162,30$ & $18.664,76$ & $18.645,62$ & $18.065,66$ \\
\hline 5. & KUBOTA LAPIS T & $40.544,75$ & $39.431,75$ & $37.414,56$ & $37.371,43$ & $37.364,46$ & $36.910,02$ \\
\hline 6. & SWL OKINA 502 HJJ B & $52.516,21$ & $48.634,22$ & $46.784,88$ & $44.862,67$ & $43.676,62$ & $41.561,01$ \\
\hline 7. & HH 112E L 20/25 & $3.835,03$ & $3.434,10$ & $3.306,84$ & $3.228,81$ & $3.006,98$ & $2.909,22$ \\
\hline 8. & KUBOTA LAPIS B & $28.812,69$ & $27.506,70$ & $26.151,16$ & $26.341,14$ & $26.736,00$ & $26.738,82$ \\
\hline 9. & SWL 05 D 10-10.5 & $218.775,44$ & $194.440,55$ & $192.340,94$ & $189.199,80$ & $185.724,35$ & $179.558,17$ \\
\hline 10. & SWL 05 SR & $250.382,97$ & $220.765,49$ & $217.080,14$ & $213.439,17$ & $206.895,36$ & $201.761,71$ \\
\hline Rata-Rata MSE & $63.131,09$ & $56.628,66$ & $55.377,55$ & $54.444,65$ & $53.301,18$ & $51.806,85$ \\
\hline
\end{tabular}




\section{B. Hasil Metode Single Exponential Smoothing}

Nilai $\alpha$ pada program peramalan dengan metode Single Exponential Smoothing yang dikembangkan dalam penelitian ini dirancang untuk dapat diinputkan oleh pengguna. Walaupun demikian, perlu disediakan standar nilai untuk $\alpha$ yang optimal sesuai dengan data yang ada. Nilai standar ini dapat digunakan sebagai dasar oleh pengguna dalam memperkirakan perubahan nilai $\alpha$ yang diinputkan sehingga hasil peramalan tidak menyimpang jauh dari kondisi riil. Nilai $\alpha$ memang seharusnya bisa berubah akibat perubahan data. Untuk menentukan nilai $\alpha$ yang optimal berdasarkan kondisi riil saat ini, dilakukan analisis terhadap data penjualan yang ada. Data yang akan digunakan dalam analisis adalah data penjualan dari bulan Juni sampai bulan Desember 2016 untuk 10 barang terlaris di tahun tersebut. Periode data yang digunakan, disesuaikan dengan periode data saat melakukan analisis metode Simple Moving Average.

Analisis dilakukan dengan menjalankan peramalan permintaan barang dari bulan Juni sampai bulan Desember 2016 dengan mengambil $\alpha=0 ; \alpha=0,1 ; \alpha=0,2 ; \alpha=0,3 ; \alpha=$ 0,$4 ; \alpha=0,5 ; \alpha=0,6 ; \alpha=0,7 ; \alpha=0,8 ; \alpha=0,9 ;$ dan $\alpha=1$. Untuk menentukan nilai $\alpha$ terbaik, digunakan Mean Square Error (MSE) dari 10 macam barang terlaris di tahun 2016. Perhitungan MSE dilakukan dengan membandingkan hasil peramalan dengan data riil (sebenarnya). Hasil perhitungan MSE dapat dilihat pada Tabel 5.

Tabel 5 menunjukkan adanya kecenderungan bahwa semakin besar nilai $\alpha$, maka rata-rata MSE semakin besar kecuali saat $\alpha=0,1$. Nilai $\alpha$ yang memberikan rata-rata MSE paling kecil adalah $\alpha=0,1$. Semua nilai $\alpha$ untuk sandal tali plintir HT adalah 0. Hal ini dikarenakan pada bulan Juni 2016 sampai Desember 2016 tidak terjadi penjualan sandal tali plintir HT. Penjualan sandal tali plintir HT banyak terjadi di awal-awal bulan tahun 2016. Untuk itu pada program yang akan dikembangkan dalam penelitian ini, default nilai $\alpha$ yang digunakan adalah 0,1 .

\section{Hasil Metode Least Square Trend}

Peramalan dengan metode Least Square Trend membutuhkan input periode peramalan dan jumlah periode yang digunakan untuk menghitung parameter metode Least Square Trend (n). Nilai n pada penelitian ini dirancang dapat diinputkan oleh pengguna, namun perlu disediakan standar nilai $n$ yang terbaik sesuai dengan data yang ada agar nilai $n$ yang nantinya diinputkan oleh pengguna tidak memberikan hasil peramalan yang jauh dari kondisi riil. Walaupun demikian, perubahan nilai $\mathrm{n}$ di kemudian hari tetap dimungkinkan melalui inputan pengguna. Untuk menentukan nilai $\mathrm{n}$ yang terbaik berdasarkan kondisi riil, dilakukan analisis terhadap data penjualan yang ada. Data yang akan digunakan dalam analisis adalah data penjualan dari bulan Juni sampai bulan Desember 2016 untuk 10 barang terlaris di tahun tersebut. Periode data yang digunakan, disesuaikan dengan periode data saat melakukan analisis metode Simple Moving Average.

Analisis dilakukan dengan menjalankan peramalan permintaan barang dari bulan Juni sampai bulan Desember 2016 dengan mengambil $\mathrm{n}=15, \mathrm{n}=30, \mathrm{n}=45, \mathrm{n}=60, \mathrm{n}=$
75, dan $n=90$. Nilai $n$ diambil mulai dari 15 hari karena metode ini cocok digunakan untuk peramalan jangka menengah. Penentuan nilai $\mathrm{n}$ yang terbaik dilakukan berdasarkan nilai rata-rata MSE dari 10 macam barang terlaris di tahun 2016. Perhitungan MSE dilakukan dengan membandingkan hasil peramalan dengan data sebenarnya. Hasil perhitungan MSE dari metode Least Square Trend dapat dilihat pada Tabel 6 .

Tabel 6 menunjukkan bahwa nilai MSE terkecil diperoleh saat $\mathrm{n}=75$. Untuk itu pada program yang akan dikembangkan dalam penelitian ini, default nilai $\mathrm{n}$ yang akan digunakan adalah 75 .

Dari hasil analisis metode Simple Moving Average, Single Exponential Smoothing dan Least Square Trends diperoleh informasi sebagai berikut:

- Metode Simple Moving Average hanya menghitung hasil peramalan berdasarkan data beberapa periode sebelumnya secara linier tanpa memperhitungkan adanya lonjakan permintaan di luar kondisi normal yang diakibatkan oleh adanya event tertentu.

- Metode Single Exponential Smoothing bertujuan memperhalus hasil peramalan dengan data yang cenderung linier, stasioner, atau cenderung stabil. Metode ini juga tidak dipengaruhi oleh trend maupun musim, sehingga untuk kasus yang digunakan, yaitu produk sepatu, jumlah permintaan sangat dipengaruhi oleh event, sehingga di waktu-waktu terjadinya event maka akan membentuk pola yang tidak linier, sehingga peramalan dengan metode ini kurang mendekati kondisi riil.

- Metode Least Square Trend mengasumsikan bahwa data cenderung bersifat linier dengan derajat kemiringan tertentu. Jadi metode ini cocok digunakan untuk data cenderung meningkat atau menurun secara linier (mengandung tren). Namun, untuk produk sepatu, jumlah permintaan cenderung stabil kecuali adanya event-event tertentu seperti permulaan sekolah (memasuki tahun ajaran baru) dan lebaran. Hal ini mengakibatkan penggunaan metode peramalan ini harus memperhitungkan dengan teliti jumlah periode yang akan digunakan untuk melakukan peramalan agar hasil estimasi trennya bagus. Kesalahan dalam memperhitungkan penggunaan jumlah periode yang digunakan dalam peramalan mengakibatkan hasil peramalan kurang atau bahkan tidak mendekati kondisi riil.

\section{Hasil Metode Modified Moving Average}

Dari kelemahan ketiga metode tersebut, diajukan metode baru yang dapat memperhitungkan permintaan tidak hanya pada waktu-waktu normal saja, namun juga pada waktuwaktu terjadinya event tertentu. Event yang dimaksud di sini adalah tanggal-tanggal tertentu yang ditandai sebagai event tertentu. Di Indonesia, event yang umum terjadi antara lain dapat dilihat pada Tabel 7.

Karena produk yang diramalkan adalah sepatu, maka event yang dianggap berpengaruh adalah event dimana umumnya masyarakat membeli sepatu baru, diperkirakan adalah event Lebaran (Idul Fitri), Natal dan Tahun Baru, Imlek serta Tahun Ajaran Baru Sekolah. Untuk event Lebaran 
(Idul Fitri), hari dimulainya pengaruh event adalah H-14, dikarenakan pemerintah Indonesia mengeluarkan aturan bahwa Tunjangan Hari Raya (THR) wajib diberikan kepada pegawai maksimum $\mathrm{H}-14$ sebelum tanggal edaran resmi libur dari pemerintah, event Imlek dimulai H-14 dari tanggal libur yang ditetapkan karena umumnya masyarakat mulai mempersiapkan Imlek 2 minggu sebelum hari $\mathrm{H}$, sedangkan event Natal dan Tahun Baru dimulai $\mathrm{H}-7$ sampai dengan $\mathrm{H}+6$ dari tanggal libur yang ditetapkan. Untuk event Tahun Ajaran Baru Sekolah berlangsung pada awal bulan Juni sampai pertengahan Juli (1 Juni sampai dengan 15 Juli). Hasil ujicoba dari sistem dilakukan terhadap aplikasi yang menerapkan metode Modified Moving Average (MoMoA), kemudian hasil peramalan dibandingkan terhadap metode Simple Moving Average, Exponential Smoothing, dan Least Square Trend. Penentuan skenario uji coba dilakukan dengan cara mencari contoh produk yang memiliki jumlah penjualan relatif merata di setiap tahunnya, setelah itu ditentukan range tanggal peramalan yang terpengaruh dalam range event tahunan. Contoh event yang digunakan dalam uji coba adalah event Lebaran (Idul Fitri), dengan tanggal mulai pengaruh event ditetapkan 14 hari (2 minggu) sebelum tanggal Lebaran dan menggunakan data penjualan tiga event sebelumnya $(\mathrm{k}=3)$. Data contoh produk yang digunakan dalam uji coba berjumlah dua produk, yaitu produk dengan kode SWL05D10,5 dan SWL05DSR, dengan tanggal cut-off 25 Juli 2013 sampai dengan 5 Agustus 2013. Tanggal ini dipilih karena event Lebaran pada tahun 2013 jatuh pada tanggal 8-9 Agustus 2013, sehingga tanggal mulai pengaruh event dimulai pada tanggal 25 Juli 2013.

Tabel 5. MSE Hasil Peramalan Dengan Metode Single Exponential Smoothing

\begin{tabular}{|c|c|c|c|c|c|c|c|c|c|c|c|}
\hline $\begin{array}{c}\text { Nama } \\
\text { Barang }\end{array}$ & $\alpha=0$ & $\alpha=0.1$ & $\alpha=0,2$ & $\alpha=0,3$ & $\alpha=0,4$ & $\alpha=0,5$ & $\alpha=0,6$ & $\alpha=0,7$ & $\alpha=0,8$ & $\alpha=\mathbf{0 , 9}$ & $\alpha=1$ \\
\hline $\begin{array}{l}\text { ANDO } \\
\text { N.HAWAII } \\
\text { MEN }\end{array}$ & $9.612,59$ & $8.374,38$ & $8.975,76$ & $9.628,43$ & $10.362,94$ & $11.197,17$ & $12.146,69$ & $13.229,94$ & $14.472,72$ & $15.911,26$ & $17.596,76$ \\
\hline $\begin{array}{l}\text { SR Ranting } \\
\text { HAK B }\end{array}$ & $5.636,82$ & $4.314,26$ & $4.526,36$ & $4.833,73$ & $5.203,27$ & $5.626,93$ & $6.105,00$ & $6.643,85$ & $7.255,08$ & $7.957,04$ & $8.777,99$ \\
\hline $\begin{array}{l}\text { TALI Plintir } \\
\text { HT }\end{array}$ & 0 & 0 & 0 & 0 & 0 & 0 & 0 & 0 & 0 & 0 & 0 \\
\hline $\begin{array}{l}\text { Kubota Lapis } \\
10-10.5\end{array}$ & $21.749,67$ & $21.286,16$ & $22.283,74$ & $23.531,36$ & $24.995,43$ & $26.700,54$ & $28.688,50$ & $31.020,25$ & $33.783,06$ & $37.098,62$ & $41.137,69$ \\
\hline $\begin{array}{l}\text { KUBOTA } \\
\text { LAPIS T }\end{array}$ & $42.241,70$ & $42.060,47$ & $43.017,76$ & $44.565,43$ & $46.692,42$ & $49.386,52$ & $52.684,58$ & $56.679,82$ & $61.526,74$ & $67.451,21$ & $74.772,00$ \\
\hline $\begin{array}{l}\text { SWL Okina } \\
502 \text { HJJ B }\end{array}$ & $48.350,74$ & $50.149,12$ & $53.400,47$ & $56.679,13$ & $60.268,22$ & $64.307,28$ & $68.909,46$ & $74.209,15$ & $80.383,62$ & $87.674,34$ & $96.419,35$ \\
\hline $\begin{array}{l}\text { HH 112E L } \\
20 / 25\end{array}$ & $5.310,00$ & $3.522,21$ & $3.704,25$ & $3.901,53$ & $4.112,33$ & $4.344,70$ & $4.605,77$ & $4.902,59$ & $5.244,58$ & $5.645,08$ & $6.123,91$ \\
\hline $\begin{array}{l}\text { KUBOTA } \\
\text { LAPIS B }\end{array}$ & $31.829,09$ & $30.153,01$ & $30.762,40$ & $32.048,15$ & $33.893,22$ & $36.252,09$ & $39.144,97$ & $42.649,44$ & $46.901,14$ & $52.101,08$ & $58.530,94$ \\
\hline $\begin{array}{l}\text { SWL 05 D } \\
10-10.5\end{array}$ & $110.407,21$ & $106.086,70$ & $111.245,11$ & $117.397,82$ & $124.883,18$ & $133.820,70$ & $144.320,31$ & $156.529,74$ & $170.649,32$ & $186.951,17$ & $205.811,12$ \\
\hline SWL 05 SR & $233.989,63$ & $238.505,86$ & $250.522,91$ & $264.789,27$ & $281.721,84$ & $301.596,92$ & $324.743,10$ & $351.551,04$ & $382.508,59$ & $418.247,41$ & $459.627,26$ \\
\hline Rata-Rata & $50.912,74$ & $\mathbf{5 0 . 4 4 5 , 2 2}$ & $52.843,88$ & $\mathbf{5 5 . 7 3 7 , 4 8}$ & $59.213,29$ & $63.323,29$ & $68.134,84$ & 73.741,58 & $80.272,49$ & $87.903,72$ & $96.879,70$ \\
\hline
\end{tabular}

Tabel 6. MSE Hasil Peramalan dengan Metode Least Square Trend

\begin{tabular}{lrrrrrr}
\hline \multicolumn{1}{c}{ Nama } & $\mathbf{n = 1 5}$ & \multicolumn{1}{c}{$\mathbf{n = 3 0}$} & $\mathbf{n = 4 5}$ & $\mathbf{n = 6 0}$ & $\mathbf{n = 7 5}$ & $\mathbf{n = 9 0}$ \\
\hline ANDO N. HAWAII MEN & $76.710,06$ & $187.312,34$ & $44.183,61$ & $14.184,27$ & $10.154,62$ & $10.343,72$ \\
\hline SR RANTING HAK B & $61.742,20$ & $9.688,67$ & $15.974,20$ & $6.264,95$ & $9.575,81$ & $5.447,08$ \\
\hline TALI PLINTIR HT & 2,79 & $759.899,22$ & $3.153 .390,22$ & $419.275,09$ & $5.362,18$ & $73.863,91$ \\
\hline KUBOTA LAPIS 10-10.5 & $971.279,59$ & $99.219,68$ & $37.866,92$ & $32.783,96$ & $31.502,35$ & $26.894,87$ \\
\hline KUBOTA LAPIS T & $1.812 .996,23$ & $448.965,11$ & $59.587,90$ & $84.271,28$ & $76.014,59$ & $65.033,38$ \\
\hline SWL OKINA 502 HJJ B & $48.350,74$ & $48.350,74$ & $48.350,74$ & $60.586,66$ & $50.018,93$ & $69.985,27$ \\
\hline HH 112E L 20/25 & $5.706,26$ & $3.463,56$ & $9.193,27$ & $7.499,41$ & $4.767,27$ & $4.090,71$ \\
\hline KUBOTA LAPIS B & $194.633,27$ & $40.704,08$ & $69.290,43$ & $64.995,58$ & $38.727,52$ & $32.741,44$ \\
\hline SWL 05 D 10-10.5 & $922.164,23$ & $359.489,36$ & $231.158,58$ & $209.913,54$ & $202.985,88$ & $207.049,53$ \\
\hline SWL 05 SR & $718.650,63$ & $346.420,90$ & $275.189,91$ & $228.064,37$ & $229.135,99$ & $226.638,27$ \\
\hline Rata-Rata & $\mathbf{4 8 1 . 2 2 3 , 6 0}$ & $\mathbf{2 3 0 . 3 5 1 , 3 7}$ & $\mathbf{3 9 4 . 4 1 8 , 5 8}$ & $\mathbf{1 1 2 . 7 8 3 , 9 1}$ & $\mathbf{6 5 . 8 2 4 , 5 1}$ & $\mathbf{7 2 . 2 0 8 , 8 2}$ \\
\hline
\end{tabular}


Tabel 7. Daftar Event di Indonesia

\begin{tabular}{rll} 
No & Nama Event & Pengaruh Event \\
\hline 1. & $\begin{array}{l}\text { Lebaran (Idul } \\
\text { Fitri) }\end{array}$ & $\begin{array}{l}\text { H-14 (mulai THR dibagikan) } \\
\text { sampai dengan H dari tanggal libur } \\
\text { yang ditetapkan }\end{array}$ \\
\hline 2. & $\begin{array}{l}\text { Natal dan } \\
\text { Tahun Baru }\end{array}$ & $\begin{array}{l}\text { H-7 sampai dengan H+6 dari } \\
\text { tanggal libur yang ditetapkan }\end{array}$ \\
\hline 3. & Imlek & $\begin{array}{l}\text { H-14 sampai dengan H dari tanggal } \\
\text { libur yang ditetapkan }\end{array}$ \\
\hline 4. & $\begin{array}{l}\text { Tahun Ajaran } \\
\text { Baru Sekolah }\end{array}$ & 1 Juni - 15 Juli \\
\hline
\end{tabular}

Tanggal selesai pengaruh event diakhiri pada tanggal 5 Agustus 2013 karena toko tutup H-3 lebaran. Evaluasi dilakukan dengan membandingkan hasil peramalan atas 2 macam barang pada periode 2 minggu sebelum event Hari Raya Idul Fitri dengan hasil riil. Barang yang digunakan untuk evaluasi adalah barang dengan kode SWL05D10,5 dan SWL05DSR. Kedua barang ini dipilih karena data penjualan riil atas barang ini lengkap selama 4 periode berturut-turut, yaitu dari tahun 2010 sampai 2015, sedangkan barang yang lain tidak terjual lengkap pada 4 periode tersebut. Peramalan dilakukan dengan 4 macam metode, yaitu Modified Moving Average (MoMoA), Simple Moving Average (SMA), Single Exponential Smoothing (SES), dan Least Square Trend (LST). Hasil peramalan beserta data penjualan riil dari kedua macam barang tersebut dapat dilihat pada Tabel 8 .

Tabel 8 menunjukkan bahwa 7 dari 12 data event atau $58,33 \%$ hasil peramalan dengan menggunakan metode MoMoA memberikan MSE lebih kecil dibandingkan dengan metode lainnya untuk tiap-tiap barang. Sedangkan metode SMA, memberikan hasil lebih baik dibandingkan metode lainnya hanya sebesar maksimal 16,68\% (2 dari 14 data event), metode SES maksimal sebesar 33,33\%, sedangkan metode LST sama sekali tidak menghasilkan MSE yang lebih kecil dari metode lainnya. Hal ini menunjukkan bahwa penggunaan metode MoMoA pada waktu terjadinya event, khususnya Hari Raya Idul Fitri menghasilkan MSE yang lebih rendah dibandingkan metode lainnya. Hasil metode MoMoa juga lebih baik dibanding Simple Moving Average (SMA) yang tidak memperhitungkan event. Namun karena nilai MSE masih cukup besar, perlu dilakukan pengembangan lebih lanjut untuk memperkecil nilai MSE dan memperbesar keakuratan hasil.

Tabel 8. Hasil Peramalan terhadap Barang Kode: SWL05D10,5 dan SWL05DSR

\begin{tabular}{|c|c|c|c|c|c|c|c|c|c|c|}
\hline \multicolumn{11}{|c|}{ Kode barang: SWL05D10,5 (Nama Barang: SWL 05 D 10-10.5) } \\
\hline \multirow[t]{3}{*}{ No } & \multirow[t]{3}{*}{ Tanggal } & \multicolumn{9}{|c|}{ Jumlah Penjualan } \\
\hline & & \multirow[t]{2}{*}{ Riil } & \multicolumn{2}{|c|}{ MoMoA } & \multicolumn{2}{|c|}{ SMA } & \multicolumn{2}{|c|}{ SES } & \multicolumn{2}{|c|}{ LST } \\
\hline & & & Hasil & MSE & Hasil & MSE & Hasil & MSE & Hasil & MSE \\
\hline 1 & $25 / 07 / 2013$ & 432 & 510 & 78 & 480 & 48 & 240 & 192 & 0 & 432 \\
\hline 2 & $26 / 07 / 2013$ & 1248 & 480 & 768 & 384 & 864 & 259 & 989 & -240 & 1488 \\
\hline 3 & $27 / 07 / 2013$ & 0 & 1308 & 1308 & 640 & 640 & 358 & 358 & -480 & 480 \\
\hline 4 & $28 / 07 / 2013$ & 0 & 144 & 144 & 560 & 560 & 322 & 322 & -720 & 720 \\
\hline 5 & $29 / 07 / 2013$ & 0 & 309 & 309 & 416 & 416 & 290 & 290 & -960 & 960 \\
\hline 6 & $30 / 07 / 2013$ & 1920 & 1254 & 666 & 0 & 1920 & 261 & 1659 & -1200 & 3120 \\
\hline 7 & $31 / 07 / 2013$ & 24 & 558 & 534 & 640 & 616 & 427 & 403 & -1440 & 1464 \\
\hline 8 & $01 / 08 / 2013$ & 2640 & 1968 & 672 & 648 & 1992 & 387 & 2253 & -1680 & 4320 \\
\hline 9 & $02 / 08 / 2013$ & 0 & 912 & 912 & 1528 & 1528 & 612 & 612 & -1920 & 1920 \\
\hline 10 & $03 / 08 / 2013$ & 186 & 132 & 54 & 888 & 702 & 551 & 365 & -2160 & 2346 \\
\hline 11 & $04 / 08 / 2013$ & 0 & 358 & 358 & 942 & 942 & 514 & 514 & -2400 & 2400 \\
\hline 12 & $05 / 08 / 2013$ & 0 & 42 & 42 & 62 & 62 & 463 & 463 & -2640 & 2640 \\
\hline \multicolumn{2}{|c|}{ Jumlah MSE Terkecil } & & & 7 & & 1 & & 4 & & $\mathbf{0}$ \\
\hline \multicolumn{11}{|c|}{ Kode barang: SWL05DSR (Nama Barang : SWL 05 D SR) } \\
\hline 1 & $25 / 07 / 2013$ & 432 & 1563 & 1131 & 2048 & 1616 & 2640 & 2208 & 2744 & 2312 \\
\hline 2 & $26 / 07 / 2013$ & 1248 & 1422 & 174 & 1544 & 296 & 2419 & 1171 & 3092 & 1844 \\
\hline 3 & $27 / 07 / 2013$ & 0 & 2688 & 2688 & 1668 & 1668 & 2370 & 2370 & 3440 & 3440 \\
\hline 4 & $28 / 07 / 2013$ & 0 & 352 & 352 & 1268 & 1268 & 2277 & 2277 & 3788 & 3788 \\
\hline 5 & $29 / 07 / 2013$ & 0 & 918 & 918 & 1124 & 1124 & 2050 & 2050 & 4136 & 4136 \\
\hline 6 & $30 / 07 / 2013$ & 1920 & 3438 & 1518 & 904 & 1016 & 1972 & 52 & 4484 & 2564 \\
\hline 7 & $31 / 07 / 2013$ & 24 & 1293 & 1269 & 1704 & 1680 & 2159 & 2135 & 4832 & 4808 \\
\hline 8 & $01 / 08 / 2013$ & 2640 & 3372 & 732 & 1716 & 924 & 1946 & 694 & 5180 & 2540 \\
\hline 9 & $02 / 08 / 2013$ & 0 & 2628 & 2628 & 2496 & 2496 & 2113 & 2113 & 5528 & 5528 \\
\hline 10 & $03 / 08 / 2013$ & 186 & 2514 & 2328 & 1548 & 1362 & 2001 & 1815 & 5876 & 5690 \\
\hline 11 & $04 / 08 / 2013$ & 0 & 380 & 380 & 1640 & 1640 & 1832 & 1832 & 6224 & 6224 \\
\hline 12 & $05 / 08 / 2013$ & 0 & 369 & 369 & 448 & 448 & 1653 & 1653 & 6572 & 6572 \\
\hline \multicolumn{2}{|c|}{ Jumlah MSE Terkecil } & & & 7 & & 2 & & 3 & & $\mathbf{0}$ \\
\hline
\end{tabular}




\section{KESIMPULAN}

Manajemen sediaan merupakan salah satu faktor yang mempengaruhi kesuksesan sebuah usaha. Salah satu cara untuk membantu mengatur sediaan adalah dengan meramalkan jumlah sediaan untuk periode mendatang. Metode Simple Moving Average merupakan salah satu metode peramalan yang banyak digunakan.

Kelemahan dari metode Simple Moving Average adalah metode ini tidak memperhitungkan adanya event pada periode peramalan sehingga hasil yang diberikan kurang mendekati hasil riil. Untuk mengatasi kelemahan tersebut, dilakukan modifikasi pada metode Simple Moving Average. Apabila peramalan dilakukan tidak pada periode terjadinya event, maka peramalan dilakukan dengan metode Simple Moving Average, namun jika peramalan dilakukan pada periode event maka data yang digunakan untuk peramalan diperhitungkan dari beberapa periode event yang sama sebelumnya. Hasil evaluasi atas metode ini menunjukkan bahwa metode Modified Moving Average (MoMoA), memberikan hasil 58\% lebih baik dibandingkan beberapa metode peramalan lainnya (Simple Moving Average (SMA), Single Exponential Smoothing (SES), Trend Least Square (TLS). Namun nilai Mean Square Error yang dihasilkan masih cukup tinggi sehingga perlu dilakukan penelitian lanjutan untuk memperkecil besarnya error.

\section{REFERENSI}

[1] Mitra, S.K. (2011). Usefulness of Moving Average Based Trading Rules in India. International Journal of Business and Management, Vol. 6 (7), pp. 199-206.

[2] Sari, A.N., Utama, I.G.A. \& Kusumawati, W.I. (2012) Perbandingan Sistem Peramalan Penjualan Dengan Metode Exponential Smoothing Dan Single Moving Averages Menggunakan Uji Statistik. Jurnal JSIKA, Vol. 1 (2), pp. 1-10.

[3] Mulyandi, B. \& Iriani, Y. (2010). Analisis Peramalan Penjualan Bahan Bakar Minyak Jenis Premium di SPBU Pahlawan Asri Bandung. National Conference Design and Application of Technology.

[4] Hermawi, A. (2007). Aplikasi Moving Average Filter Pada Teknologi Enkripsi. Jurnal TESLA, Vol. 9(1), pp. 33-35.

[5] Taylor III, B.W. (2008). Introduction to Management Science, Edisi 8. Jakarta: Penerbit Salemba Empat.

[6] Shih, S.H. \& Tsokos, C.P. (2008). A Weighted Moving Average Process for Forecasting. Journal of Modern Applied Statistical Methods, Vol. 7(1), pp. 187-197.

[7] Hung, N.H. \& Zhaojun, Y. (2013). Profitability of Applying Simple Moving Average Trading Rules for the Vietnamese Stock Market. Journal of Business \& Management, Vol. 2(3), pp. 22-31.

[8] Margi, K \& Pendawa, S. (2015). Analisa Dan Penerapan Metode Single Exponential Smoothing Untuk Prediksi Penjualan Pada Periode Tertentu (Studi Kasus: PT.
Media Cemara Kreasi). Seminar Hasil Penelitian dan Pengabdian Masyarakat Dana BOPTN. ISBN: 978602-14917-3-7.

[9] OTexts. (2017). Simple Exponential Smoothing. Diakses dari dari https://otexts.com/fpp2/ses.html

[10] Holt, C.C. (1957). Forecasting Seasonals and Trends by Exponentially Weighted Moving Averages. ONR Memorandum, Vol. 52. Pittsburgh: Carnegie Institute of Technology.

[11] Tratar, L.F., Mojškerc, B. \& Toman A. (2016). Demand Forecasting with Four-Parameter Exponential Smoothin. International Journal of Production Economics, Vol. 181 (part A), pp. 162-173.

[12] Stikom Open Course. (2012). Metode Pemulusan Eksponensial (Exponential Smoothing Method).

[13] Lima, S., Gonçalves, A.M. \& Costa, M. (2019). Time Series Forecasting Using Holt-Winters Exponential Smoothing: An Application to Economic Data. AIP Conference Proceedings 2186, 09000, DOI: 10.1063/1.5137999.

[14] Wua, L., Liu, S. \& Yang, Y. (2016). Grey Double Exponential Smoothing Model and Its Application on Pig Price Forecasting in China. Applied Soft Computing, Vol. 39, pp. 117-123.

[15] Burger, C.J.S.C., Dohnal, M., Kathrada, M. \& Law, R. (2001). A Practitioner's Guide to Time-Series Methods for Tourism Demand Forecasting - a Case Study of Durban, South Africa. Tourism Management, Vol. 22(4), pp. 403-409.

[16] Taylor, J.W. (2010). Triple Seasonal Methods for ShortTerm Electricity Demand Forecasting. European Journal of Operational Research, Vol. 204(1), pp. 139152.

[17] Lind, D. (2015). Connect Online Access for Statistical Techniques in Business and Economics (16th ed). McGraw-Hill.

[18] Winston, W.L. (2004). Operations Research: Applications and Algorithms. USA: Brooks/ColeThomson Learning.

[19] Almuhtadi, W., Murphy, D.R. \& Rosberg, M. (2010). Implementing Trend Identification With Least Squares Method Into Commtest on an Intelligent Satellite Services Network for Throughput Measurement. Electrical and Computer Engineering (CCECE), Proceedings of the 23rd Canadian Conference on Electrical and Computer Engineering (CCECE 2010), Calgary, Alberta, Canada.

[20] Yu, L., Chen, H., Wang, S. \& Lai, K.K. (2009). Evolving Least Squares Support Vector Machines for Stock Market Trend Mining. IEEE Transactions on Evolutionary Computation, Vol. 13(1), pp. 87-102.

[21] Lin, K.P. \& Pai, P.F. (2016). Solar Power Output Forecasting Using Evolutionary Seasonal Decomposition Least-Square Support Vector Regression. Journal of Cleaner Production, Vol. 134(part B), pp. 456-462. 